\title{
RAPID LATERAL DIFFUSION OF EXTRAJUNCTIONAL ACETYLCHOLINE RECEPTORS IN THE DEVELOPING MUSCLE MEMBRANE OF XENOPUS TADPOLE ${ }^{1}$
}

\author{
STEVEN H. YOUNG AND MU-MING $\mathrm{POO}^{2}$ \\ Department of Physiology and Biophysics, University of California, Irvine, California 92717
}

Received May 20, 1982; Revised July 22, 1982; Accepted July 22, 1982

\begin{abstract}
We have studied the lateral diffusion of acetylcholine (ACh) receptors in the extrajunctional region of developing myotomal muscle cell membrane of Xenopus tadpoles by a technique of local inactivation. The myotomal muscle cell surfaces of Xenopus tadpoles were exposed to external solution by gently removing the skin of the tail. The density of ACh receptors was monitored by membrane depolarizations in response to iontophoretically applied pulses of ACh. A pulse of $\alpha$ bungarotoxin was pressure ejected onto the exposed fiber surface, resulting in a rapid local inactivation of the $\mathrm{ACh}$ receptors. With time, the functional $\mathrm{ACh}$ receptors diffused into the region of inactivation, producing a recovery of ACh response. That the observed recovery of ACh sensitivity is due to diffusion of $\mathrm{ACh}$ receptors from the unexposed undersurface of the fiber to the inactivated region was evidenced by the following: (1) no recovery was observed following prolonged toxin application; (2) pretreatment of the muscle cells with concanavalin $\mathrm{A}$, which cross-links and immobilizes ACh receptors, prevented recovery; (3) mapping of ACh response along the muscle cell axis showed that the recovery cannot be accounted for by diffusion along the longitudinal axis of the fiber; and (4) the diffusion coefficients observed after scaling the recovery rate with fiber radius fell within a small range $\left(1.5\right.$ to $\left.4.0 \times 10^{-9} \mathrm{~cm}^{2} / \mathrm{sec}\right)$, consistent with diffusion of ACh receptors around the fiber circumference. This finding of rapid lateral diffusion within developing tadpole myotomal muscle membrane supports the notion that the localization of $\mathrm{ACh}$ receptors induced by innervation could be achieved by a "diffusion-trap" mechanism where the nerve contact region serves as a trap for rapidly diffusing receptors in the membrane.
\end{abstract}

It has been shown in many preparations that in early embryonic muscle membrane, the distribution of ACh receptors is widespread. As the neuromuscular junction matures, the density of junctional ACh receptors increases and that of extrajunctional receptors decreases (Hartzell and Fambrough, 1973; Fischbach and Cohen, 1973; Cohen and Fischbach, 1977; Chow and Cohen, 1978; Chow, 1980). In adult skeletal muscle, $\mathrm{ACh}$ receptors are located predominantly at the postsynaptic membrane (Fertuck and Salpeter, 1974; Porter and Barnard, 1975). The mechanism for such a change in ACh receptor topography during development is unknown. Chao et al. (1981) have investigated a simple mechanism by which mobile membrane molecules may become trapped at a small region of the membrane. Such a "diffusion-trap" scheme was shown to be plausible in accounting for the

\footnotetext{
${ }^{1}$ This work was supported by Grant BNS-8012348 from the National Science Foundation. S. H. Y. was supported by a postdoctoral fellowship from the Muscular Dystrophy Association.

${ }^{2}$ To whom correspondence should be addressed.
}

localization of muscle surface soybean agglutinin receptors induced by cell-cell contact in culture. It could also account for the localization of $\mathrm{ACh}$ receptor induced by nerve-muscle contact in culture (Anderson and Cohen, 1977; Frank and Fischback, 1979), if the diffusion coefficient of the ACh receptors is on the order of $10^{-9} \mathrm{~cm}^{2}$ / sec or higher (Edwards and Frisch, 1976; Poo, 1982). Although Poo (1982) has measured the diffusion coefficient for ACh receptors in cultured Xenopus myotomal muscle cells to be $2.6 \times 10^{-9} \mathrm{~cm}^{2} / \mathrm{sec}$, it is not clear whether ACh receptors are capable of rapid lateral diffusion within intact developing tissue. In fact, no measurement of the mobility of functional membrane protein within intact tissue has ever been reported.

In the present study, we have determined the diffusion coefficient of functional $\mathrm{ACh}$ receptors in Xenopus tadpole myotomal muscle cell membrane by an electrophysiological technique. The value obtained (1.5 to $4.0 \times 10^{-9}$ $\mathrm{cm}^{2} / \mathrm{sec}$ ) is large enough to allow simple diffusion as a plausible mechanism for $\mathrm{ACh}$ receptor localization during synaptogenesis. 


\section{Materials and Methods}

The basic experimental arrangement is diagrammed in Figure 1. An intracellular micropipette $V$ measures cell membrane depolarization to pulses of $\mathrm{ACh}$ delivered through an iontophoretic pipette $A$. A small pulse of $\alpha$ bungarotoxin $(\alpha$-BGT) is pressure ejected through pipette $T$ onto the myotomal muscle cell surface near the tip of pipette $A$. The binding of $\alpha$-BGT to ACh receptors, which is irreversible in the time scale of these experiments ( $\leqslant 1 \mathrm{hr}$ ), blocks the ACh-induced membrane depolarization. Diffusion of toxin-free ACh receptors into the region of the tip of pipette $A$ is monitored by an increase in membrane depolarization to the same doses of iontophoretically applied ACh.

Preparation of myotomal cells. Tadpoles of Xenopus laevis were staged by the criteria of Nieuwkoop and Faber (1967). We used tadpoles from stages 38 to 46 , during which high $\mathrm{ACh}$ receptor density has been found along the myotomal muscle cells (Chow, 1980). Tadpoles were placed in Steinberg's saline solution containing anesthetic $\left(58 \mathrm{~mm} \mathrm{NaCl}, 0.7 \mathrm{~mm} \mathrm{KCl}, 0.4 \mathrm{~mm} \mathrm{Ca}\left(\mathrm{NO}_{3}\right)_{2}\right.$, $0.1 \mathrm{mM} \mathrm{MgSO}_{4}, 4.6 \mathrm{~mm}$ Tris, $\mathrm{pH} 7.8$; Tricaine MS-222, $10^{-4} \mathrm{gm} / \mathrm{ml}$, Sandoz), where skin, head, and viscera were gently removed, leaving the skinned tail. The tail then was transferred to a small Sylgard-lined Petri dish and pinned out on its side, and the bathing solution was changed to saline containing $300 \mathrm{~mm}$ tetrodotoxin and 10 $\mathrm{mm} \mathrm{CaCl}$.

Preparation of pipettes. The voltage-recording pipette was a glass micropipette filled with $3 \mathrm{M}$ potassium acetate (resistance, 80 to 120 megohms). The ACh-containing pipette was a glass micropipette filled with 3 м ACh (resistance, 100 to 140 megohms). The toxin pipette was a thin glass tube with an inner diameter of 5 to $10 \mu \mathrm{m}$ filled with saline containing $\alpha$-BGT ( $50 \mu \mathrm{g} / \mathrm{ml})$ and small latex beads ( $0.8 \mu \mathrm{m}$ diameter; Sigma Chemical Co.). The beads provided a direct visual monitoring of toxin solution flow in and out of the pipette.

Positioning of pipettes and drift. The voltage and toxin pipettes were mounted on hydraulic drive micromanipulators (Narashige). The ACh pipette was mounted on a pneumatic drive micromanipulator (de Fonbrune, Curtin Scientific Co.), chosen for low drift characteristics. Tests of drift showed drift $<1 \mu \mathrm{m}$ in any direction $(X, Y, Z)$ for $20 \mathrm{~min}$.

Protocol. After the tail was mounted, the chamber was placed on the stage of a binocular compound microscope equipped with a long working distance lens. Since the neuromuscular synapses are located predominantly at the ends of the cell (Kullberg et al., 1977), the voltage pipette was inserted into the middle of a muscle cell on the outer surface of the tail (resting potential, -90 to $-115 \mathrm{mV}$ ), and the $\mathrm{ACh}$ pipette was placed near the voltage pipette. Braking current ( 2 to $4 \mathrm{nA}$ ) was applied through the ACh pipette to prevent leakage of ACh between pulses. After stable membrane potential and ACh-induced depolarizations were recorded, the toxin pipette was brought to within $7 \mu \mathrm{m}$ of the tip of the ACh pipette. A small pressure-ejected pulse of $\alpha$-BGT quickly inactivated $\mathrm{ACh}$ receptors in the region of the tip, as measured by decreased depolarization to iontophoretically applied ACh. Suction was applied immediately after toxin ejection to the toxin pipette to clean up free
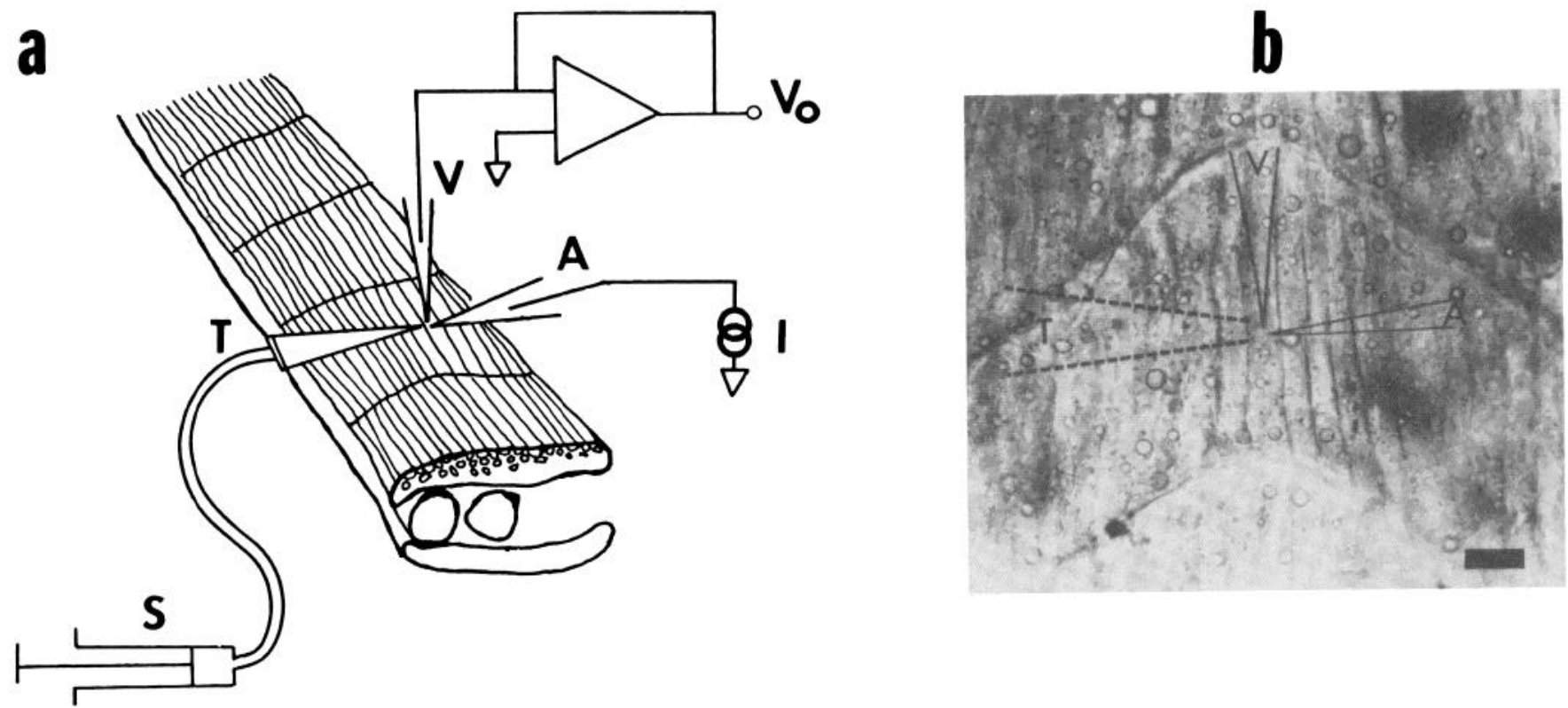

Figure 1. $a$, Schematic diagram of the system for measuring recovery of ACh response after local inactivation by $\alpha$-bungarotoxin. A voltage-recording pipette $(V)$ is inserted into a myotomal muscle fiber on the surface of the myotome. The output voltage $V_{o}$ is obtained from a buffer amplifier. Short pulses of ACh are ejected onto the surface of the cell iontophoretically through pipette $A$ with constant current source $I$. A short pulse of the toxin $\alpha$-bungarotoxin $(50 \mu \mathrm{g} / \mathrm{ml})$ is pressure ejected onto the fiber surface through pipette $T$ (inner diameter, 5 to $10 \mu \mathrm{m}$ ) by moving the plunger of a $50-\mu$ l syringe $S$. After toxin ejection, the plunger is withdrawn, producing a slight vacuum which sweeps up free toxin from solution. $b$, A photomicrograph of the surface of a skinned tail of a stage 45 tadpole, showing myotomes and the position of the voltage pipette $(V)$, the ACh pipette $(A)$, and the toxin pipette $(T)$. Scale bar represents $40 \mu \mathrm{m}$. 
toxin in the surrounding medium. In time, as noninactivated $\mathrm{ACh}$ receptors diffused into the previously inactivated region, the membrane response to $\mathrm{ACh}$ recovered. All experiments were performed at room temperature $\left(23^{\circ} \mathrm{C}\right)$.

Receptor density. The ACh-induced conductance of the membrane is proportional to the number of active ACh receptors (Katz and Miledi, 1972; Anderson and Stevens, 1973). The change in membrane potential, $\Delta V$, is related to the ACh conductance $g$ by (Land et al., 1977):

$$
g=\frac{V}{R_{\text {in }}\left(E_{m}-E_{r}-\Delta V\right)}
$$

where $R_{\text {in }}$ is the input resistance of the fiber, $E_{m}$ is the resting potential, and $E_{r}$ is the reversal potential of the ACh conductance channel. In the experiments used in our analysis of the diffusion coefficient, $E_{m}$ was about $-100 \mathrm{mV}, \boldsymbol{E}_{r}$ was about $-10 \mathrm{mV}$ (Blackshaw and Warner, 1976), and $\Delta V$ was adjusted to be about $10 \mathrm{mV}$ by controlling the ACh delivered to the muscle. With a maximum error of about 13\%, the conductance (and therefore the receptor density) may be taken to be pro- portional to $\Delta V$. In many experiments, voltage records were taken with AC-coupled amplification. In these records, the maximum error in determining receptor density changes is about $20 \%$.

\section{Results}

Figure 2 illustrates recovery of $\mathrm{ACh}$ response after local inactivation of ACh receptors by local $\alpha$-BGT ejection. The rate and extent of recovery of ACh response is highly dependent upon the rate of toxin ejection and the amount of toxin ejected. Figure 2, $a$ and $b$, shows recovery of ACh response to $30 \%$ and $70 \%$ of preinactivation levels after initial complete local inactivation. Figure $2 c$ illustrates almost full recovery after partial inactivation. In Figure $2 d$, no significant recovery is seen after a large pulse of toxin.

Figure 3 illustrates experiments in which recovery was monitored by a train of ACh pulses of constant amplitude. In Figure $3 a$, partial recovery of $\mathrm{ACh}$ responses is seen within $3 \mathrm{~min}$ following inactivation. The fiber of Figure $3 b$ was pretreated with concanavalin A (Con A; $100 \mu \mathrm{g} / \mathrm{ml}$, Sigma), a treatment known to immobilize $\mathrm{ACh}$ receptors (Orida and Poo, 1978). With similar in-
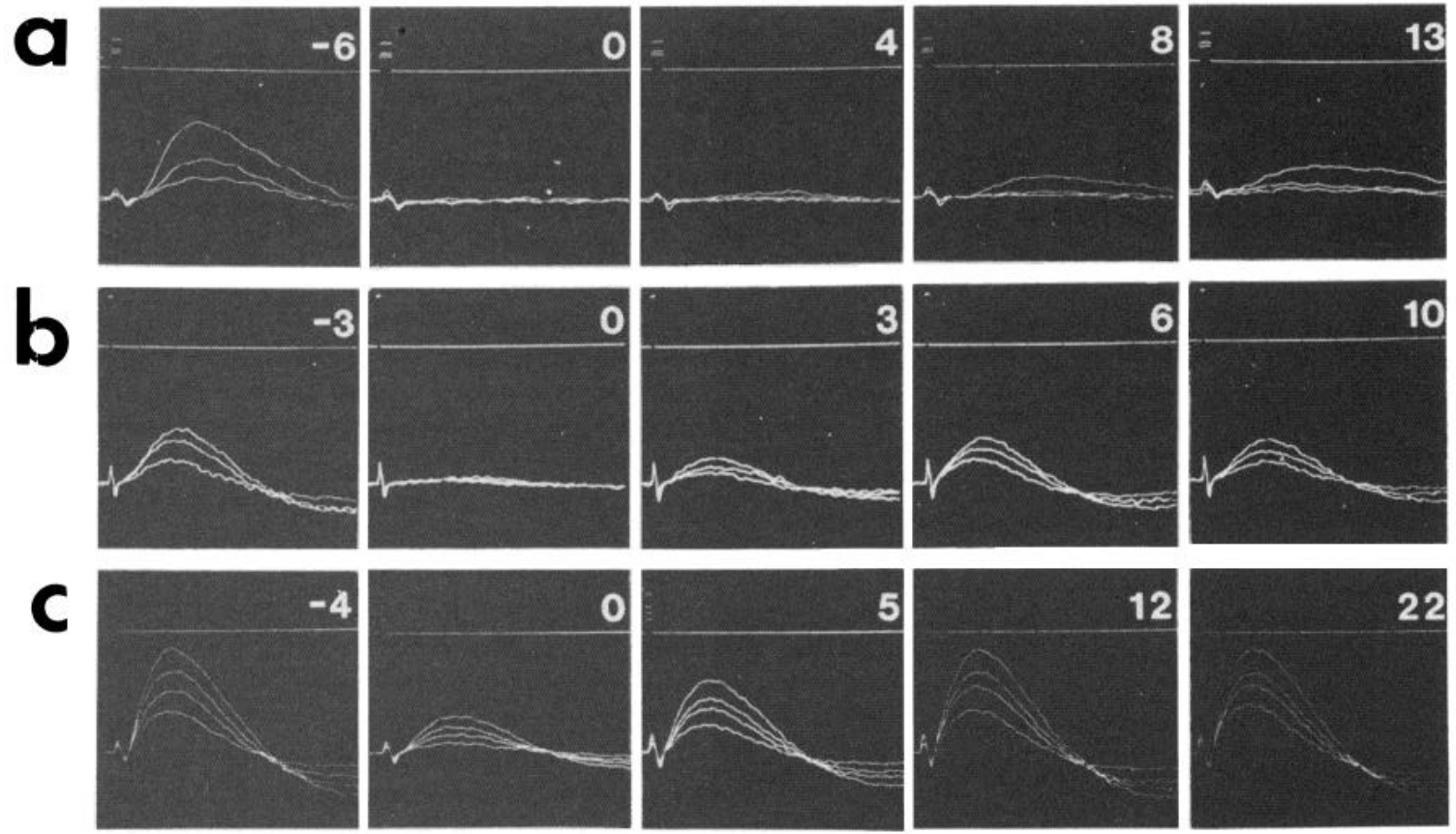

d
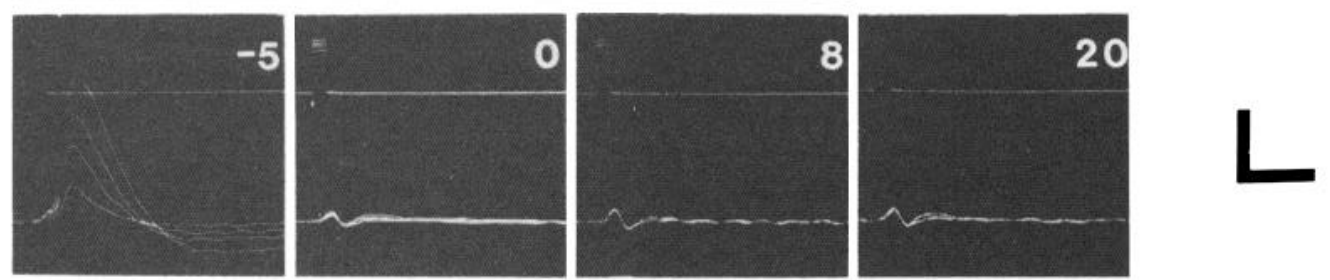

Figure 2. Typical examples of the recovery of ACh response after local inactivation by $\alpha$-bungarotoxin. The upper traces monitor the current used to eject $\mathrm{ACh}$; the lower traces depict membrane depolarization in response to a series of ACh current pulses of increasing amplitudes (a.c. recording). Each row represents one recovery experiment. The same set of current pulses was used throughout each experiment. The number above each set of traces is the time (in minutes) from the completion of toxin ejection (duration of toxin ejection was $<1 \mathrm{~min}$ ). The data from the experiments of rows $a$ and $b$ show recovery of ACh response to $30 \%$ and $70 \%$ of the preinactivation values, respectively, after initial complete inactivation. In the experiment shown in row $c$, recovery to almost $100 \%$ after partial inactivation is seen. In row $d$, no recovery occurred after a large pulse of toxin. Vertical bar: $5 \mathrm{mV}$ and $10 \mathrm{nA}(d), 20 \mathrm{nA}(a$ and $b), 50 \mathrm{nA}(c)$. Horizontal bar: $20 \mathrm{msec}(d)$ and $50 \mathrm{msec}(a, b$, and $c)$. 


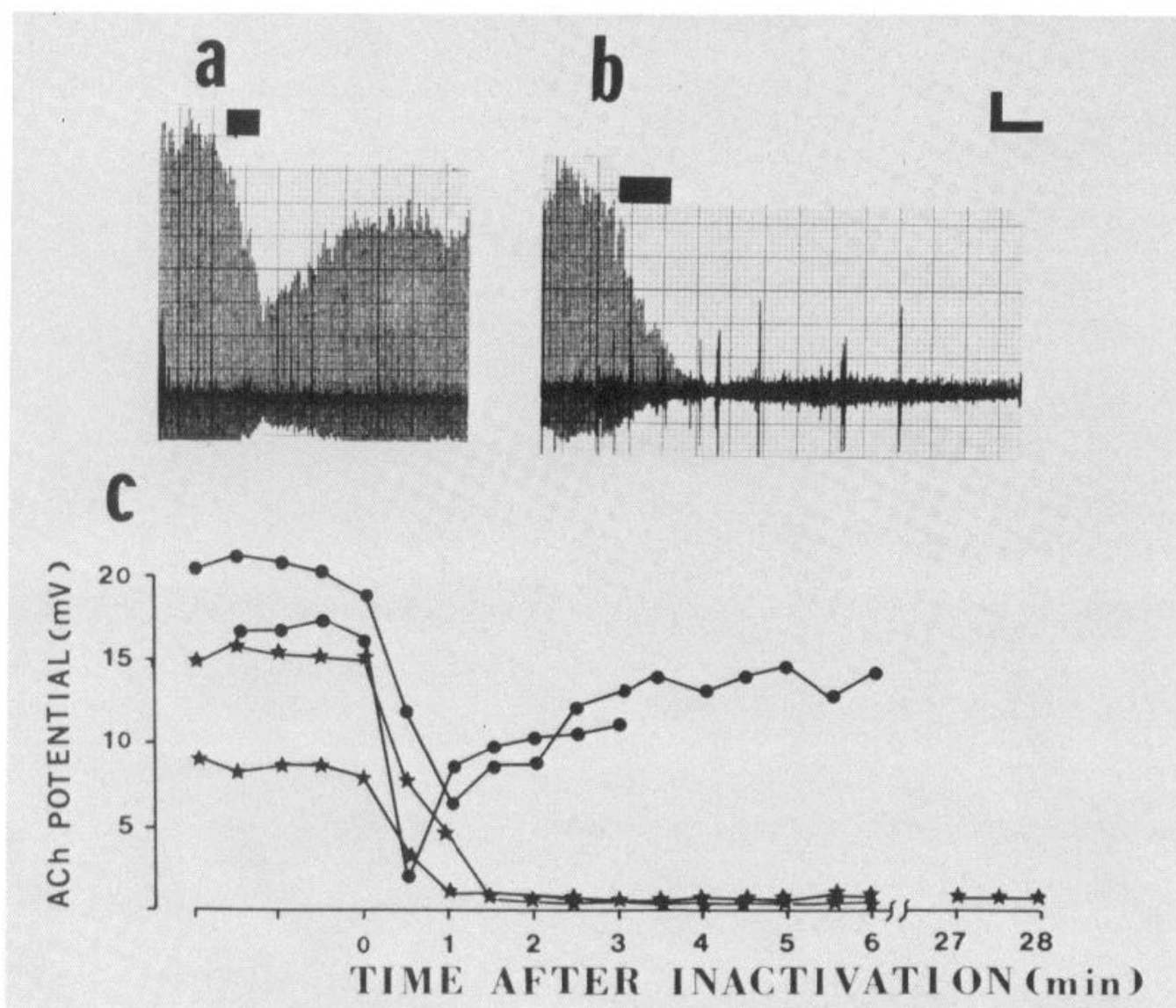

Figure 3. Recovery of membrane voltage response to ACh after inactivation by $\alpha$-bungarotoxin monitored by a train of constant amplitude pulses of $\mathrm{ACh}$. $a$, A single pulse of toxin (duration indicated by heavy bar) produced a decline of ACh potential followed by recovery to about $75 \%$ of the original level. $b$, A fiber pretreated with Con A ( $100 \mu \mathrm{g} / \mathrm{ml} \mathrm{for} 18 \mathrm{~min})$, which cross-links and immobilizes ACh receptors, shows no recovery after toxin application. Transients appearing in the record are due to invading miniature endplate potentials. AC coupling was used. Vertical bar, $2.5 \mathrm{mV}$; horizontal bar, 1 min. $c$, Peak ACh potentials of Figure 2, $a$ and $b$, are plotted as a function of time after completion of toxin pulse. Data from two other fibers (original records not shown) are also plotted. $\bullet$, data from untreated myotomal cells; $\star$, data from cells pretreated with Con $\mathrm{A}$.

activation as that in Figure $3 a$, no recovery was observed up to $8 \mathrm{~min}$ after toxin ejection. Figure $3 c$ plots peak ACh-induced potentials vs. time from the data of Figure $3, a$ and $b$, together with data from two other cells. We noticed that treatment with Con $\mathrm{A}$ resulted in a slight decrease in the ACh sensitivity of the membrane. Greater iontophoretic current thus was used to induce sufficient membrane depolarization. Whether the Con A effect is due to direct modification of the channel or an alteration in the electrical properties of the membrane is currently under investigation.

To simplify the analysis of diffusion of ACh receptors, we followed membrane depolarizations to constant amplitude test pulses of $\mathrm{ACh}$ in time, with the immediate post-toxin response being $0 \mathrm{mV}$ or near $0 \mathrm{mV}(<1 \mathrm{mV})$. This requires application of enough toxin to completely inactivate $\mathrm{ACh}$ receptors in the local region without a large spread of toxin along and around the cell that would either prevent recovery (within the time frame of these experiments) or permit recovery to only very low levels. Of 29 fibers studied, 20 showed recovery, with 4 recovering to less than $20 \%$ the original ACh potential, 12 recovering to 20 to $50 \%$, and 4 recovering to levels greater than $50 \%$ of the original level. In other similar experiments, fibers were preincubated with saline containing
Con A $(100 \mu \mathrm{g} / \mathrm{ml})$ for $10 \mathrm{~min}$. In 11 of 11 cells, no recovery of ACh response was observed after local inactivation.

After local inactivation, toxin-free $\mathrm{ACh}$ receptors will diffuse into the inactive zone from around the circumference of the fiber as well as along the length of the fiber. However, examination of the equations which describe diffusion of receptors in these two directions show that the dominant (fastest) component of recovery is due to circumferential diffusion of receptors.

The equation describing diffusion of receptors around the circumference of a circular cylinder into a region devoid of receptors is given by:

$$
\frac{C(t)}{C(\infty)}=1+\sum_{n=1}^{\infty} A_{n} e^{-n^{2} D t / r^{2}} \quad n=1,2,3, \cdots
$$

where $C(t)$ is the receptor concentration measured at the center of the inactivated region at time $t$ and $C(\infty)$ is the concentration at infinite time. $A_{n}$ represents coefficients which depend upon the initial pattern and extent of inactivation, $D$ is the diffusion coefficient, and $r$ is the radius of the cylinder. The first order $(n=1)$ time constant is $r^{2} / D$.

To examine the longitudinal spread of inactivation, we 
mapped ACh response along the length of six fibers before and immediately after toxin application (Fig. 4). There was no significant $\mathrm{ACh}$ response up to $50 \mu \mathrm{m}$ from the original site of the tip of the ACh pipette. The inactivated area thus covered a substantial fraction of the entire fiber, which has an average length of about 200 $\mu \mathrm{m}$. An analysis of longitudinal diffusion under such conditions of inactivation produces the first order time constant of $L^{2} / 4 \pi^{2} D$, where $L$ is the length of the muscle fiber. Since the first order time constant for the circumferential diffusion is $r^{2} / D$ and the fiber length is at least 14 times the radius, the characteristic time for longitudinal diffusion is approximately 5 times slower than that of the circumferential diffusion. Therefore, in our analysis of the diffusion of $\mathrm{ACh}$ receptors, the first detectable recovery phase of $\mathrm{ACh}$ response was assigned to the diffusion around the circumference of the fiber.

Data from the recovery experiments which showed 20 to $50 \%$ recovery were pooled. Since the recovery rate

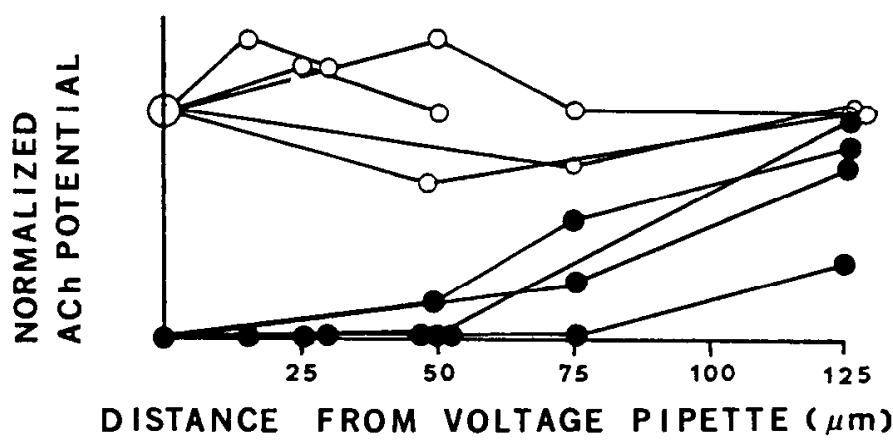

Figure 4. The extent of toxin inactivation along the fiber axis. The original site of the tip of the ACh pipette is taken as $0 \mu \mathrm{m}$. Before toxin application (open circles), the ACh pipette was moved to various distances away from the origin. The response to $\mathrm{ACh}$ (for identical current pulses) is normalized to the value at $0 \mu \mathrm{m}$. After toxin application (solid circles), the response to $\mathrm{ACh}$ was again mapped. around the circumference depends on the square of the radius, we pooled the recovery data by scaling the time coordinate by $r^{2}$, as shown in Figure 5 . For a single cell, starting at time zero, there was a delay in the first appearance of $\mathrm{ACh}$ response which was followed by an approach to steady state. This delay was seen in all fibers showing a final recovery level that was less than $50 \%$ of the pre-toxin ACh potential. Consistent with the notion that the observed recovery is due primarily to diffusion of $\mathrm{ACh}$ receptors around the circumference of the fiber, we found that there is a "time-compression" of data from fibers of different diameter by scaling with the radius, a behavior expected only from circumferential diffusion. For example, the time to reach one-half maximum recovery for the largest fiber $(r=15 \mu \mathrm{m})$ was $21 \mathrm{~min}$; for the smallest fiber $(r=10 \mu \mathrm{m})$ it was $8 \mathrm{~min}$, a ratio of 2.6 . If the times are scaled by the square of the radii, the ratio becomes 1.16 , a value much closer to unity. To estimate the diffusion coefficient $(D)$, we assume that the initial inactivation was uniform and it covered an area equal to one-half of the muscle fiber surface (i.e., the exposed surface). Under these initial conditions, solution of equation 1 yielded results shown in Figure 5. The solid lines in Figure 5 correspond to $D=1.5 \times 10^{-9} \mathrm{~cm}^{2} / \mathrm{sec}$ and $D$ $=4.0 \times 10^{-9} \mathrm{~cm}^{2} / \mathrm{sec}$. The best fit (by eye) line represents $D=2.5 \times 10^{-9} \mathrm{~cm}^{2} / \mathrm{sec}$.

\section{Discussion}

We have presented data of the recovery of membrane response to $\mathrm{ACh}$ after irreversible $\alpha$-BGT inactivation, and we have used these data to determine the diffusion coefficient of functional $\mathrm{ACh}$ receptors. Consideration should be given to the following possible experimental conditions which could result in apparent recovery of response but which are not related to diffusion.

Electrical artifact. It is possible that under repetitive current pulses, the $\mathrm{ACh}$ pipette and associated circuitry could change the amount of ACh delivered, producing a

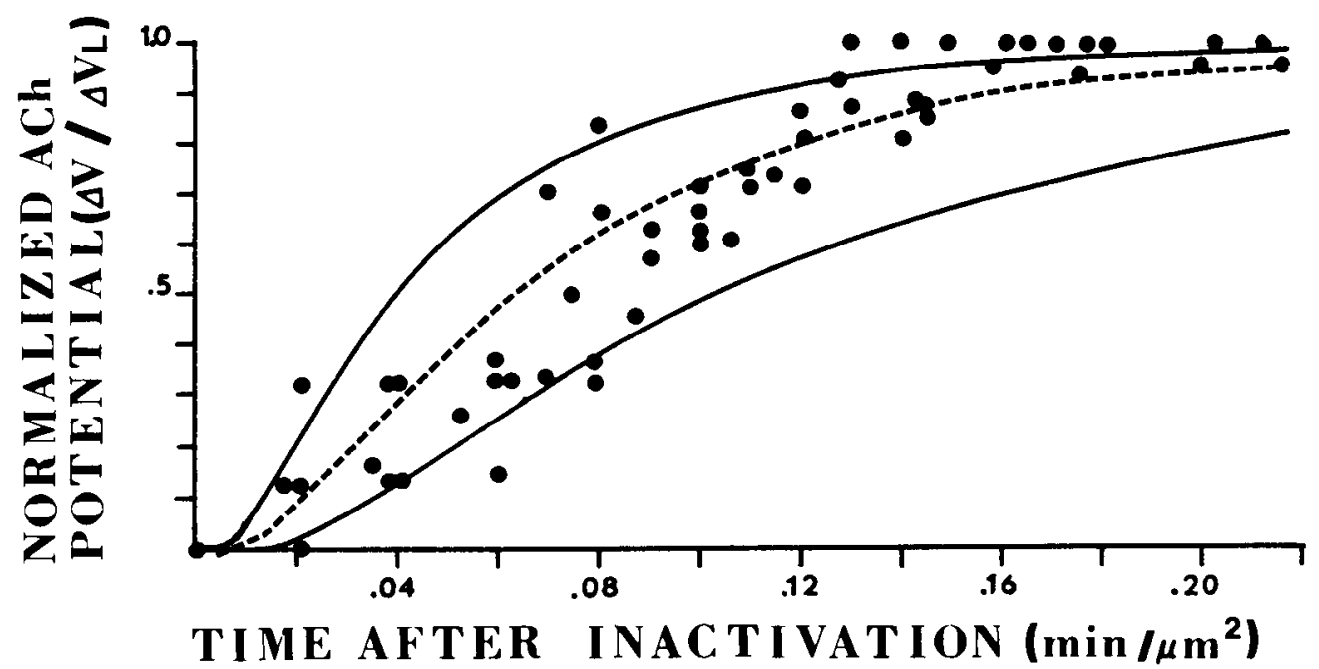

Figure 5. The time course of recovery of ACh-induced depolarization response after toxin inactivation. The peak response to a fixed pulse of $\mathrm{ACh}$ at time $t$ is normalized to the value at long times $\left(\Delta V / \Delta V_{L}\right)$ and the time was scaled to the square of the radius of the fiber $\left(t / r^{2}\right)$. Time $t=0$ is immediately after toxin application. The solid circles represent pooled data from fibers that recovered to 20 to $50 \%$ of the pre-toxin level. The solid lines are recovery curves calculated according to equation 1 of the text, with an initial uniform inactivation that covered an area equal to one-half of the fiber circumference, with $D=1.5 \times 10^{-9}$ $\mathrm{cm}^{2} / \mathrm{sec}$ and $4.0 \times 10^{9} \mathrm{~cm}^{2} / \mathrm{sec}$. The dashed curve represents a best fit (by eye), corresponding to $D=2.5 \times 10^{-9} \mathrm{~cm}^{2} / \mathrm{sec}$. 

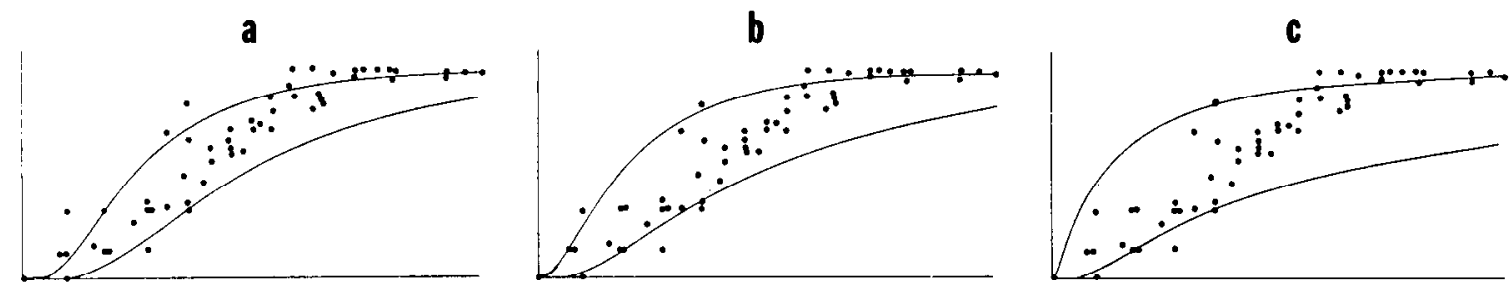

Figure 6. Recovery data fitted by theoretical curves representing different areas of initial inactivation. $a$, Area of inactivation covers three-fourths of the fiber circumference; $D=2.0$ and $4.0 \times 10^{-9} \mathrm{~cm}^{2} / \mathrm{sec} . b$, Area of inactivation covers one-half of the fiber circumference; $D=1.5$ and $4.0 \times 10^{-9} \mathrm{~cm}^{2} / \mathrm{sec}$. $c$, Area of inactivation covers one-fourth of the fiber circumference; $D=0.5$ and $3.0 \times 10^{-9} \mathrm{~cm}^{2} / \mathrm{sec}$. The extent of inactivation was assumed to be uniform across the entire inactivated area.

false increase in post-inactivation recovery. This possibility is ruled out in two ways: (1) the iontophoresis system provides a current monitor circuit, and no change in current delivery was observed, and (2) long-term pulsing of ACh onto a fiber without toxin inactivation did not produce an increase in $\mathrm{ACh}$-induced membrane potential change.

Mechanical artifact. Movement of the $\mathrm{ACh}$ pipette to a different membrane area during the course of the experiment could produce a change in $\mathrm{ACh}$ response. As pointed out under "Materials and Methods," we chose a micromanipulator with very small drfit $(<1 \mu \mathrm{m}$ in 20 $\min$ ). The inactivated region, as shown in Figure 4 , is much more extensive than the range over which $\mathrm{ACh}$ pipette drift could possibly occur. Furthermore, as described above, under long-term pulsing of $\mathrm{ACh}$ without toxin application, no drift in the response to $\mathrm{ACh}$ was observed.

Recovery of membrane response which is not due to diffusion. The application of toxin might affect the membrane in such a way as to increase ACh receptor density without redistribution of preexisting receptors. The possibility of fast local insertion of ACh receptors was ruled out by flooding the entire membrane with toxin, in order to inactivate a very large population of $\mathrm{ACh}$ receptors. No recovery was seen under these conditions. In fact, recovery can be observed only by carefully controlling the pressure through the toxin pipette to achieve rapid and local inactivation. Slight increases in pressure and/ or ejection time usually prevented recovery. Further evidence that recovery is linked to lateral redistribution was provided by pretreatment of the fiber with Con $\mathrm{A}$, a tetravalent ligand which is known to immobilize ACh receptors (Orida and Poo, 1978; Poo, 1982). This is consistent with the idea that binding of Con $\mathrm{A}$ to the $\mathrm{ACh}$ receptors prevents diffusion of ACh receptors (and therefore recovery of $\mathrm{ACH}$ response).

The exact pattern and extent of toxin inactivation around the circumference of the fiber is not known. We are guided by the final level of recovery in estimating the original toxin-inactivated boundaries. In particular, we have chosen recovery data from fibers whose recovery levels were 20 to $50 \%$ of original values and have compared their time courses to theoretical curves calculated for an initial uniform inactivation that covers an area exactly one-half of the circumference of the fiber.

We have also compared theoretical curves resulting from different initial patterns of inactivation, as seen in Figure 6 . When the initial inactivated area is less than or equal to one-fourth of the circumference, there is very little initial lag in the recovery, and no value of $D$ will adequately fit the data. When the inactivated area covers three-fourths of the circumference, values of $D$ from 2 to $4 \times 10^{-9} \mathrm{~cm}^{2} / \mathrm{sec}$ will fit the data. For simplicity, the extent of inactivation was assumed to be uniform across the entire inactivated area (i.e., sharp-edge boundary conditions). By assuming a characteristic smooth profile for the extent of inactivation, better theoretical fit of the data could be established, especially for the initial points immediately after inactivation. For a first order estimate, however, the simple calculation of varying the area of inactivation indicated that the diffusion coefficient obtained is rather insensitive to the pattern of initial inactivation.

We have not attempted to determine experimentally the exact pattern of initial receptor inactivation around the circumference of the muscle fiber. The ACh receptors on the undersurface of the fiber are inaccessible to direct electrophysiological mapping. As for the histochemical staining method, the slow diffusion of fixatives through the intercellular space could greatly reduce the time resolution required for determining the initial pattern of inactivation. Slow diffusion of molecules in the intercellular space could also result in trapping of ejected $\alpha$-BGT which would be relatively inaccessible to clean-up upon application of negative pressure (suction) to the toxin pipette. This would produce further receptor inactivation during the course of the experiment. Such residual action of ejected $\alpha$-BGT will slow the rate of recovery of ACh response at the exposed region of the fiber. The actual diffusion coefficient of functional $\mathrm{ACh}$ receptors could then be larger than the value determined by the apparent recovery rate of ACh response. Axelrod et al. (1976) have previously reported a diffusion coefficient of ACh receptors in cultured rat myotubes of $5 \times 10^{-11} \mathrm{~cm}^{2} / \mathrm{sec}$, a value 50 times slower than that reported here and in a previous study in Xenopus muscle cells in culture (Poo, 1982). Since the study by Axelrod et al. (1976) was carried out by a different experimental method (fluorescence photobleaching recovery) on a different preparation, further experiments are required to elucidate the cause of this discrepancy in the values of the diffusion coefficient. The photobleaching method requires attachment of fluorescently labeled $\alpha$-BGT to the ACh receptor. It thus measures the diffusion of toxin-receptor complexes rather than that of the free receptors. The former could experience much higher viscous drag due to the presence of an extracellular matrix of glycocalyx. Another possibility for the cause of discrepancy is that only a fraction of $\alpha$ $\mathrm{BGT}$ binding sites are ACh receptors, detectable by our 
electrophysiological method, while the photobleaching method measures diffusion of all membrane components that bind to $\alpha$-BGT.

In the developing Xenopus embryo, neuromuscular synapses occur predominantly at the ends of the myotomal cells (Kullberg et al., 1977). Chow (1980) has found marked accumulation of $\mathrm{ACh}$ receptors at the ends of the myotomes (as well as an increase along the myotomes) between stages 22 and 36 , a span of about $26 \mathrm{hr}$. On assuming that the ends of the myotomal cell serve as traps for freely diffusing ACh receptors, solution of the diffusion equation produces a first order time constant for the trapping of receptors of $L^{2} / \pi^{2} D$. For a myotomal cell length of $200 \mu \mathrm{m}$, and $D=2.5 \times 10^{-9} \mathrm{~cm}^{2} / \mathrm{sec}$, the first order time constant is $4.5 \mathrm{hr}$. Within $18 \mathrm{hr}$ (four time constants), accumulation of ACh receptors would be $98 \%$ complete.

In summary, the value of the diffusion coefficient of ACh receptors in intact tissue is similar to that found in cell culture from the same tissue (Poo, 1982). This finding of rapid lateral diffusion of $\mathrm{ACh}$ receptors supports the idea of simple diffusional redistribution as a mechanism for receptor localization during synaptogenesis.

\section{References}

Anderson, C. R., and C. F. Stevens (1973) Voltage clamp analysis of acetylcholine produced end-plate current fluctuations at frog neuromuscular junction. J. Physiol. (Lond.) 235: 655-691.

Anderson, M. J., and M. W. Cohen (1977) Nerve-induced and spontaneous redistribution of acetylcholine receptors on culture muscle cells. J. Physiol. (Lond.) 268: 757-773.

Axelrod, D., R. Radvin, D. E. Koppel, J. Schlessinger, W. W. Webb, E. L. Elson, and T. R. Podleski (1976) Lateral motion of fluorescently labeled acetylcholine receptors in membranes of developing muscle cells. Proc. Natl. Acad. Sci. U. S. A. 73: 4594-4598.

Blackshaw, S., and A. Warner (1976) Onset of acetylcholine sensitivity and end-plate activity in developing myotome muscles of Xenopus. Nature 262: 217-218.

Chao, N. -m., S. H. Young, and M. -m. Poo (1981) Localization of cell membrane components by surface diffusion into a "trap." Biophys. J. 36: 139-153.

Chow, I. (1980) Distribution of acetylcholine receptors in the myotomes of Xenopus laevis during normal development. Doctoral thesis, McGill University, Montreal, Quebec, Can- ada.

Chow, I., and M. W. Cohen (1978) Distribution of acetylcholine receptors in the myotomes of Xenopus laevis during normal development. Soc. Neurosci. Abstr. 4: 368.

Cohen, S. A., and G. D. Fischbach (1977) Clusters of acetylcholine receptors located at identified nerve-muscle synapses in vitro. Dev. Biol, 59: 24-39.

Edwards, C., and H. L. Frisch (1976) A model for the localization of acetylcholine receptors at the muscle end-plate. J. Neurobiol. 7: 377-381.

Fertuck, H. C., and M. M. Salpeter (1974) Localization of acetylcholine receptor by ${ }^{125}$ I-labelled $\alpha$-bungarotoxin binding at mouse motor end-plates. Proc. Natl. Acad. Sci. U. S. A. 71: 1376-1378.

Fischbach, G. D., and S. A. Cohen (1973) The distribution of acetylcholine sensitivity over uninnervated and innervated muscle fibers grown in cell culture. Dev. Biol. 31: 147-162.

Frank, E., and G. D. Fischbach (1979) Early events in neuromuscular junction formation in vitro-Induction of acetylcholine receptor clusters in the postsynaptic membrane and morphology of newly formed synapses. J. Cell Biol. 83: 143158.

Hartzell, H. C., and D. M. Fambrough (1973) Acetylcholine receptor production and incorporation into membranes of developing muscle fibers. Dev. Biol. 30: 153-165.

Katz, B., and R. Miledi (1972) The statistical nature of the acetylcholine potential and its molecular components. J. Physiol. (Lond.) 244: 703-730.

Kullberg, R. W., T. L. Lentz, and M. W. Cohen (1977) Development of the myotomal neuromuscular junction in Xenopus laevis: An electrophysiological and fine structural study. Dev. Biol. 60: 101-129.

Land, B. R., T. R. Podleski, E. E. Salpeter, and M. M. Salpeter (1977) Acetylcholine receptor distribution on myotubes in culture correlated to acetylcholine sensitivity. J. Physiol. (Lond.) 269: 155-176.

Nieuwkoop, P. D., and J. Faber (1967) Normal Table of Xen. opus Laevis (Dauden), Ed. 2, Elsevier-North Holland Publishing Co., Ansterdarn.

Orida, N., and M. -m. Poo (1978) Electrophoretic movement and localization of acetylcholine receptors in embryonic muscle cell membrane. Nature 275: 31-35.

Poo, M. M. (1982) Rapid lateral diffusion of acetylcholine receptors in the embryonic muscle cell membrane. Nature 295: 332-334.

Porter, C. N., and E. A. Barnard (1975) The density of cholinergic receptors at the end-plate postsynaptic membrane: Ultrastructural studies in two mammalian species. J. Membr. Biol. 20: 31-49. 